\title{
RES-701-1, A NOVEL AND SELECTIVE ENDOTHELIN TYPE B RECEPTOR ANTAGONIST PRODUCED BY Streptomyces sp. RE-701 \\ I. CHARACTERIZATION OF PRODUCING STRAIN, FERMENTATION, ISOLATION, PHYSICO-CHEMICAL AND BIOLOGICAL PROPERTIES
}

\author{
Yoshikazu Morishita*, Shigeru Chiba, Elut Tsukuda, Takeo Tanaka, Tatsuhiro Ogawa, \\ Motoo Yamasaki, Mayumi Yoshida, Isao Kawamoto ${ }^{\dagger}$ and Yuzuru Matsuda \\ Tokyo Research Laboratories, Kyowa Hakko Kogyo Ltd., \\ 3-6-6 Asahimachi, Machida-shi, Tokyo 194, Japan \\ †Tsukuba Reseach Laboratories, Kyowa Hakko Kogyo Ltd., \\ 2-Miyukigaoka, Tsukuba-shi, Ibaragi 305, Japan
}

(Received for publication October 14, 1993)

\begin{abstract}
RES-701-1, a novel cyclic peptide endothelin antagonist, was isolated from the culture broth of Streptomyces sp. RE-701. RES-701-1 selectively inhibited the ET-1 binding to type B endothelin receptor $\left(\mathrm{ET}_{\mathrm{B}}\right.$ receptor) with an $\mathrm{IC}_{50}$ of $10 \mathrm{nM}$ expressed in CHO cells and blocked the ET-1-induced elevation of intracellular free $\mathrm{Ca}^{2+}$ concentration in $\mathrm{ET}_{\mathrm{B}}$ receptor-expressing COS-7 cells. Characterization of producing strain, fermentation, isolation, structure, physico-chemical and biological properties of RES-701-1 are described.
\end{abstract}

Endothelins (ETs) are a family of three related peptides, endothelin 1, 2, and 3 (ET-1, ET-2 and ET-3), which have a variety of biological activities in both vascular and non-vascular tissues, including hemodynamic, cardiac, pulmonary and renal effects. Circulating levels of ET-1 have been found to be elevated in some pathophysiological conditions such as systemic hypertension, cardiac ischemia, asthmatic attacks and cyclosporin-induced renal failure. These observations suggest that specific blockage of endothelin actions at receptor level can be potential treatment of disease states caused by elevated levels of $\operatorname{ETs}^{1,2)}$.

In our microbial screening for endothelin antagonists using bovine lung membranes, we isolated a novel cyclic peptide RES-701-1 from the fermentation broth of Streptomyces sp. RE-701. RES-701-1 selectively inhibited ET-1 binding to type $\mathrm{B}$ endothelin receptor $\left(\mathrm{ET}_{\mathrm{B}}\right.$ receptor) expressed in $\mathrm{CHO}$ cells and blocked the ET-1-induced elevation of intracellular free $\mathrm{Ca}^{2+}$ concentration in $\mathrm{ET}_{\mathrm{B}}$ receptor-expressing COS-7 cells. This paper describes the characterization and fermentation of the producing strain and the isolation, physico-chemical properties and biological activities of RES-701-1. Details of the structure determination are described in the succeeding paper ${ }^{3)}$

\section{Materials and Methods}

Materials

(3-[125I]Iodotyrosyl $\left.{ }^{13}\right)$ endothelin-1 was purchased from Amersham Japan. Endothelin-1 (ET-1) was purchased from Peptide Institute, Inc., Osaka, Japan. Bovine lung was obtained from a local slaughterhouse. The human B type endothelin receptor gene was the generous gift of Dr. Hirose (Department of Biological Science, Tokyo Institute of Technology, Tokyo, Japan.) All other chemicals were of analytical grade. 
Characterization of the Producing Strain

Strain RE-701 that produced RES-701-1, endothelin antagonist, was isolated from a soil sample collected in Aichi Prefecture, Japan. For cultural and physiological characterization of the producing strain, the methods of SHIRLING and GotrLIeB ${ }^{4)}$ were employed. The cultural and physiological characterization except a liquefaction test of gelatin were determined after incubation at $28^{\circ} \mathrm{C}$ for 2 weeks. Liquefaction of gelatin was determined after incubation at $20^{\circ} \mathrm{C}$ for 2 weeks. The temperature range for growth of the strain was determined after submerged cultivation for 1 week. For analysis of the configuration of diaminopimelic acid in whole-cell hydrolysate of strain RE-701, the method of HASEGAWA, TAKIZAWA, and TANIDA ${ }^{5)}$ was employed.

\section{Culture and Medium Conditions}

A loopful of Streptomyces sp. RE-701 from a mature slant was inoculated into $10 \mathrm{ml}$ of the seed medium composed of glucose $1 \%$, soluble starch $1 \%$, Bacto-Tryptone (Difco) $0.5 \%$, Yeast extract (Nihon-Seiyaku) $0.5 \%$, Beef extract (Kyokuto) $0.3 \%, \mathrm{KH}_{2} \mathrm{PO}_{4}, 0.1 \%, \mathrm{MgSO}_{4} \cdot 7 \mathrm{H}_{2} \mathrm{O} 0.05 \%, \mathrm{CaCO}_{3}$ $0.2 \%$ (pH 7.2 before sterilization) in a test tube $(21 \mathrm{~mm} \times 200 \mathrm{~mm}$ ). The inoculated tube was incubated at $28^{\circ} \mathrm{C}$ for 4 days. A $10 \%$-inoculation from the above seed medium was added to a 300 -ml Erlenmeyer flask containing $50 \mathrm{ml}$ of the same medium. After incubation for 2 days on a rotary shaker $(200 \mathrm{rpm})$ at $28^{\circ} \mathrm{C}$, a $10 \%$-inoculation from the above seed medium was added to the third stage seed in a $300-\mathrm{ml}$ Erlenmeyer flask containing $50 \mathrm{ml}$ of the seed medium and incubated for 2 days on a rotary shaker $(200 \mathrm{rpm})$ at $28^{\circ} \mathrm{C}$. The $800 \mathrm{ml}$ of seed culture, prepared as above, was transferred to 8 liters of the fermentation medium containing soluble starch $4 \%$, soy bean meal $1 \%$, corn steep liquor $0.5 \%$, dry yeast (Asahi Brewery) $0.5 \%$, $\mathrm{KH}_{2} \mathrm{PO}_{4} 0.05 \%$, HP-20 resin (Mitsubishi-Kasei) $10 \%, \mathrm{ZnSO}_{4} \cdot 7 \mathrm{H}_{2} \mathrm{O} 10 \mu \mathrm{g} / \mathrm{ml}, \mathrm{CoCl}_{2} \cdot 6 \mathrm{H}_{2} \mathrm{O} 1 \mathrm{mg} / \mathrm{ml}$, $\mathrm{NiSO}_{4} 1 \mathrm{mg} / \mathrm{ml}, \mathrm{Mg}_{3}\left(\mathrm{PO}_{4}\right)_{2} \cdot 8 \mathrm{H}_{2} \mathrm{O} 0.05 \%$ (pH 7.0 before sterilization) in one hundred and eighty of $300-\mathrm{ml}$ Erlenmeyer flasks. The fermentation was carried out at $28^{\circ} \mathrm{C}$ for 4 days on a rotary shaker $(200 \mathrm{rpm})$. The production of RES-701-1 was monitored by measuring an inhibitory activity against [ $\left.{ }^{125} \mathrm{I}\right] \mathrm{ET}-1$ binding to bovine lung membranes. For this measurement, the cultured broth was sampled and mixed with an equal volume of methanol. The resultant mixture was stirred vigorously and centrifuged. An aliquot $(10 \mu \mathrm{l})$ of the supernatant was provided for the assay.

\section{Preparation of Membranes}

For preparation of bovine lung membranes, lung parenchyma were dissected and homogenized with a polytron (settings 8 for 30 seconds $\times 2$ ) in 5 volumes of buffer A containing $1 \mathrm{~mm} \mathrm{NaHCO}, 5 \mathrm{~mm}$ EDTA (pH 8.3), $5 \mu \mathrm{g} / \mathrm{ml}$ Leupeptin, $5 \mu \mathrm{g} / \mathrm{ml}$ Pepstatin A, and $40 \mu \mathrm{M}$ phenylmethylsulfonyl fluoride. The homogenates were centrifuged at $8,000 \times g$ for 10 minutes. The supernatants were then centrifuged at $40,000 \times g$ for 1 hour at $4^{\circ} \mathrm{C}$. The pellets were homogenized in buffer $A$ and recentrifuged at $40,000 \times g$ for 1 hour. The resulting pellets were homogenized in buffer $A$ supplemented with $130 \mathrm{~mm} \mathrm{NaCl}, 5 \mathrm{~mm} \mathrm{Na}{ }_{2} \mathrm{HPO}_{4}$ and $1.5 \mathrm{~mm} \mathrm{KH}_{2} \mathrm{PO}_{4}$ and stored at $-70^{\circ} \mathrm{C}$. For preparation of CHO cell membranes, transfected cells were washed with PBS and removed from the culture dish with a rubber policeman and collected by centrifugation. The resulting cell pellets were used to obtain the membrane preparation as described above.

\section{ET-1 Receptor Assay}

The reaction mixture $(1 \mathrm{ml})$ containing $0.74 \mathrm{kBq} / \mathrm{ml}\left[{ }^{125} \mathrm{I}\right] \mathrm{ET}-1,50 \mathrm{~mm}$ Tris-HCl buffer ( $\left.\mathrm{pH} 7.6\right), 1 \mathrm{~mm}$ EDTA, $0.2 \%$ bovine serum albumin (BSA), $0.02 \%$ bacitracin, $14 \mu \mathrm{g}$ of lung membrane protein or CHO cell membranes, and various concentration of samples was incubated at room temperature for 2 hours, then filtered through GF/B glass filters. The glass filters were washed three times with cold $50 \mathrm{~mm}$ Tris- $\mathrm{HCl}$ buffer containing $1 \mathrm{mM}$ EDTA by a Brandel M-24R cell harvester. The radioactivity on the washed filter was measured by using a Packard $\gamma$ counter. Non specific binding was measured in the presence of $0.1 \mu \mathrm{M}$ of unlabeled ET-1.

Expression of Cloned Human type A and type B Endothelin Receptors in COS-7 and CHO Cells

Human $\mathrm{ET}_{\mathrm{A}}$ receptor genes were obtained from human placenta mRNA by reverse transcription and PCR methods. Human $\mathrm{ET}_{\mathrm{A}}$ and $\mathrm{ET}_{\mathrm{B}}$ receptor genes were cloned into pcDNA I vector (Invitrogen) for transient expression in COS-7 cells or were cloned into pAGE107 whose promoter was replaced by the one of Momulv for stable expression in $\mathrm{CHO}$ cells as described ${ }^{6)}$. Resulting $\mathrm{ET}_{\mathrm{A}}$ or $\mathrm{ET}_{\mathrm{B}}$ receptor gene 
was introduced to COS-7 cells as described ${ }^{7)}$ and cultured in DulBECCo's modified EAGLE's medium supplemented with $10 \%$ fetal calf serum. After 3 days cultivations, the COS-7 cells were provided for the studies on intracellular $\mathrm{Ca}^{2+}$ concentration measurement. For stable expression of $\mathrm{ET}_{\mathrm{A}}$ and $\mathrm{ET}_{\mathrm{B}}$ receptors, the genes were introduced to $\mathrm{CHO}$ cells, and $\mathrm{ET}_{\mathrm{A}}$ or $\mathrm{ET}_{\mathrm{B}}$ receptors-expressing cells were selected as described $^{6}$. Then, the cells were cultured in a minimal essential medium supplemented with $10 \%$ dialysed bovine calf serum, but without ribonucleosides and deoxyribonucleosides. Binding experiments were performed with membranes prepared from the transfected CHO cells.

\section{Measurement of Intracellular $\mathrm{Ca}^{2+}$ Concentration}

The transfected COS-7 cells were plated on a glass coverslip with a silicon rubber wall (Heraeus, Flexiperm). The culture was maintained for 3 days with the DulbeCco's modified EAGLE's medium supplemented with $10 \%$ fetal calf serum in a humidified atmosphere of $5 \% \mathrm{CO}_{2}$ in air at $37^{\circ} \mathrm{C}$. After cultivation, culture medium was removed, and the cells on the coverslip were washed at least three times with a basal salt solution (BSS: $\mathrm{NaCl} 140 \mathrm{mM}, \mathrm{KCl} 4 \mathrm{mM}, \mathrm{CaCl}_{2} 1.25 \mathrm{mM}$, D-glucose $11 \mathrm{~mm}, \mathrm{MgCl}_{2} \cdot 6 \mathrm{H}_{2} \mathrm{O}$ $1 \mathrm{mM}, \mathrm{Na}_{2} \mathrm{HPO}_{4} \cdot 12 \mathrm{H}_{2} \mathrm{O} 1 \mathrm{~mm}$, BSA $1 \mathrm{mg} / \mathrm{ml}$, HEPES-NaOH $5 \mathrm{~mm} ; \mathrm{pH}$ was adjusted to 7.4). Fura-2/AM $(10 \mu \mathrm{M})$ in BSS was then incubated with the cells for 60 minutes at $37^{\circ} \mathrm{C}$ and washed extensively with BSS. The coverslip with transfected COS-7 cells that had been loaded with fura- 2 was filled with $1 \mathrm{ml}$ BSS, ET-1 and/or RES-701-1 were then added to the cells. Fluorescence measurements were carried out at $37^{\circ} \mathrm{C}$ using an ARUGAS 2000 system (Hamamatsu Photonics). Excitation was at 340 or $380 \mathrm{~nm}$, and emission intensity was measured at $510 \mathrm{~nm}$. The concentration of $\mathrm{Ca}^{2+}$ was estimated by comparison with the fluorescence intensity ratios of $\mathrm{Ca}^{2+}$-EGTA mixtures in MOPS (3-( $N$-morpholino)propanesulfonic acid) buffer added to $10 \mu \mathrm{M}$ fura- 2 and excited at the two wavelengths.

\section{Results}

\section{Characterization of the Producing Strain}

Vegetative hyphae of strain RE-701 were well developed, branched, and did not fragment into bacillary or coccoid elements. Aerial mycelia were formed on various agar media. Spore chains were born on the aerial mycelia in spiral form with rows of 10 to 50 spores. The spores were smooth-surfaced and non-motile. The formation of sporangia or synnemata was not observed. The configuration of diaminopimelic acid in whole-cell hydrolysate of strain RE-701 was LL-form. Based on taxonomic characteristics described above, strain RE-701 is considered to belong to the genus Streptomyces. The cultural characteristics of the producing strain are shown in Table 1. The aerial mass color was in the

Table 1. Cultural characteristics of strain RE-701.

\begin{tabular}{|c|c|c|c|}
\hline Medium & Substrate mycelium & Aerial mycelium & $\begin{array}{l}\text { Soluble } \\
\text { pigment }\end{array}$ \\
\hline $\begin{array}{l}\text { Yeast extract - malt extract } \\
\text { agar (ISP No. 2) }\end{array}$ & Good, mustard gold (2ne) & Moderate, white (a) & None \\
\hline Oatmeal agar (ISP No. 3) & Moderate, golden olive ( $\left.1 \frac{1}{2} \mathrm{lg}\right)$ & Moderate, lamp black (p) & None \\
\hline $\begin{array}{l}\text { Inorganic salts - starch agar } \\
\text { (ISP No. 4) }\end{array}$ & Good, mustard (2le) & $\begin{array}{l}\text { Abundant, white } \sim \text { lamp black } \\
(a \sim p)\end{array}$ & None \\
\hline $\begin{array}{l}\text { Glycerol - asparagine agar } \\
\text { (ISP No. 5) }\end{array}$ & Poor, yellow tint ( $\mathrm{ba}$ ) & Scanty, white (a) & None \\
\hline Tyrosine agar (ISP No. 7) & Poor, honey gold (2ic) & Scanty, white (a) & None \\
\hline Sucrose - nitrate agar & Moderate, honey gold (2ic) & Moderate, white $\sim$ gray $(a \sim f)$ & None \\
\hline Glucose-asparagine agar & Moderate, putty $\left(1 \frac{1}{2} \mathrm{ec}\right)$ & Moderate, white (a) & None \\
\hline Nutrient agar & Moderate, light wheat (2ea) & Moderate, white (a) & None \\
\hline
\end{tabular}

Color names and numbers used in this table were based on Color Harmony Manual (Container Corporation of America). 
Table 2. Physiological characteristics of strain RE-701.

\begin{tabular}{lc}
\hline Temperature for growth & $10 \sim 40^{\circ} \mathrm{C}$ \\
Optimum temperature & $25 \sim 30^{\circ} \mathrm{C}$ \\
Liquefaction of gelatin & + \\
Hydrolysis of starch & + \\
Coagulation of milk & + \\
Peptonization of milk & + \\
Formation of melanin & - \\
Utilization of: & \\
D-Glucose & + \\
L-Arabinose & - \\
D-Xylose & $\mathrm{d}$ \\
D-Fructose & + \\
Sucrose & + \\
Inositol & + \\
L-Rhamnose & - \\
Raffinose & + \\
D-Mannitol & + \\
\hline
\end{tabular}

+ , Positive; - , negative; d, doubtful.

grey color series. No soluble pigment was produced on tested agar media. The physiolosical characteristics of strain RE-701 are shown in Table 2. The strain has been deposited in the National Institute of Bioscience and Human-Technology, Agency of Industrial Science and Technology, Japan, as Streptomyces sp. RE-701 with the accession No. FERM-BP3624.

\section{Isolation and Purification}

The isolation procedure of RES-701-1 is outlined in Fig. 1. Fractionation was guided by inhibition of $\left[{ }^{125} \mathrm{I}\right] \mathrm{ET}-1$ binding to bovine lung membranes. The mycelial cake was obtained by centrifugation $(7,000 \mathrm{rpm}, 20$ minutes) of the fermentation broth ( 8 liters) and extracted with methanol ( 5 liters) followed by acetone ( 5 liters). $\left[{ }^{125}\right.$ I]ET-1 displacing activity was mainly found in the acetone extract. The acetone extract was diluted with 5 liters of water and adsorbed on a Diaion HP-20 column (1 liter). After being washed with $25 \%$ aqueous acetone ( 4 liters), the active fractions were eluted with methanol (5 liters). The eluate was concentrated in vacuo to give a crude oily residue $(2.45 \mathrm{~g})$. This residue was dissolved in $100 \mathrm{ml}$ of methanol and this solution was mixed with $40 \mathrm{ml}$ of ODS gel. After the solvent of the slurry was evaporated, the resulting dry powder was added to the top of a ODS-gel column $(260 \mathrm{ml})$ which was prepacked with $30 \%$ acetonitrile in $0.1 \%$ tifluoroacetic acid (TFA). $\left.{ }^{125} \mathrm{I}\right] \mathrm{ET}-1$ displacing activity was eluted with a linear gradient of $\mathrm{CH}_{3} \mathrm{CN}$ in $0.1 \%$ TFA ( $30 \sim 50 \%$ in 100 minutes, flow rate $9 \mathrm{ml} / \mathrm{minute}$ ) and the active fractions were pooled, adjusted to $\mathrm{pH} 7$, and then desalted on a Diaion HP-20 column $(100 \mathrm{ml})$. This purification procedure was repeated and the desalted eluate from Diaion HP-20 column $(100 \mathrm{ml})$ was concentrated and dissolved in $3.7 \mathrm{ml}$ of methanol. This solution was chromatographed on a Sephadex LH-20 column equilibrated and eluted with

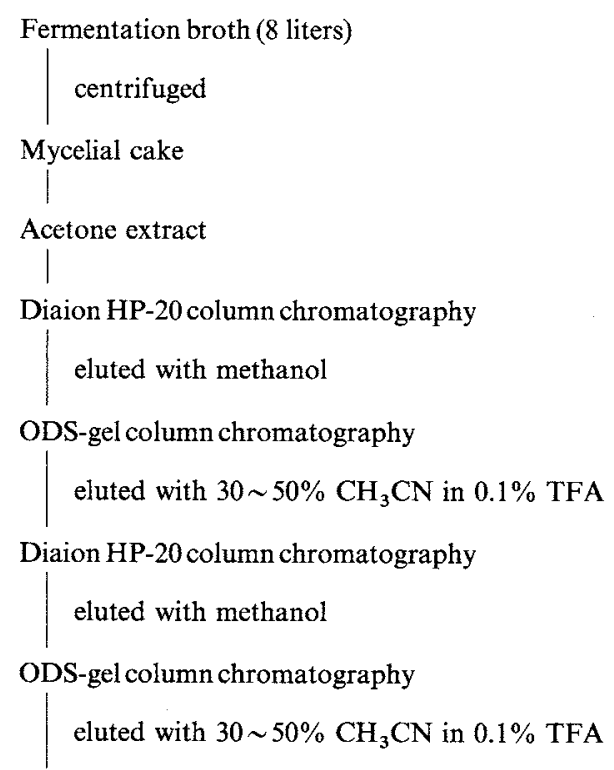

Diaion HP-20 column chromatography eluted with methanol

Sephadex LH-20 column chromatography eluted with methanol

ODS-HPLC eluted with $30 \sim 50 \% \mathrm{CH}_{3} \mathrm{CN}$ in $0.1 \%$ TFA

Diaion HP-20 column chromatography eluted with methanol

RES-701-1

(6.5 mg) 
methanol. The active fractions were pooled and purified by preparative HPLC using a YMC SH-363-10 column (ODS, $30 \times 250 \mathrm{~mm}$, YMC Co., Ltd.) with a $30 \sim 50 \% \mathrm{CH}_{3} \mathrm{CN}$ gradient elution in $0.1 \%$ TFA ( $0 \sim 10$ minutes, from 30 to $50 \%$, linear; $10 \sim 20$ minutes at $50 \%$; flow rate $20 \mathrm{ml} /$ minute). The retention time of RES-701-1 was 16.3 minutes. The active eluate was diluted with water, adjusted to $\mathrm{pH} 7$ and then desalted on a HP- 20 column $(40 \mathrm{ml})$. The evaporation of the solvent gave $6.5 \mathrm{mg}$ of RES-701-1 as a white powder.

\section{Physico-chemical Properties of RES-701-1}

Physico-chemical properties of RES-701-1 are summarized in Table 3. RES-701-1 is readily soluble in methanol, acetonitrile, and dimethyl sulfoxide, and virtually insoluble in chloroform, acetone, and water. The molcular formula of RES-701-1 was determined to be $\mathrm{C}_{103} \mathrm{H}_{115} \mathrm{~N}_{23} \mathrm{O}_{23}$ on the basis of HRFAB-MS. The structure of RES-701-1 was determined as shown in Fig. 2 on the basis of HRFAB-MS, peptide sequencing, and amino acid analysis. Details of structural elucidation studies are described in the succeeding paper ${ }^{3}$.

\section{Biological Properties}

Table 3. Physico-chemical properties of RES-701-1.

\begin{tabular}{ll}
\hline Appearance & Colorless powder \\
$\mathrm{UV} \lambda_{\max } \mathrm{nm}(\mathrm{MeOH})$ & 221,280 \\
$\mathrm{IR}(\mathrm{KBr}) \mathrm{cm}^{-1}$ & $3375,2925,1660,1515,1455$, \\
& $1440,1405,1340,1235,1105$ \\
Molecular formula & $\mathrm{C}_{103} \mathrm{H}_{115} \mathrm{~N}_{23} \mathrm{O}_{23}$ \\
HRFAB-MS & $2,042.8614$ \\
Calcd $(\mathrm{M}+\mathrm{H})^{+}$ & $2,042.8722$ \\
Found $(\mathrm{M}+\mathrm{H})^{+}$ & 0.4 \\
Rf value on TLC & Plate; Silica gel $\mathrm{F}_{254}$ \\
& Solvent; $\mathrm{CHCl}-\mathrm{MeOH}-$ \\
& EtOH - $\mathrm{H}_{2} \mathrm{O}(10: 4: 4: 2)$ \\
& 0.3 Plate: $\mathrm{RP}-18$ \\
Solvent; $80 \% \mathrm{MeOH}$
\end{tabular}

Fig. 3. Effect of RES-701-1 on the specific binding of $\left[{ }^{125} \mathrm{I}\right] \mathrm{ET}-1$ to bovine lung membranes.

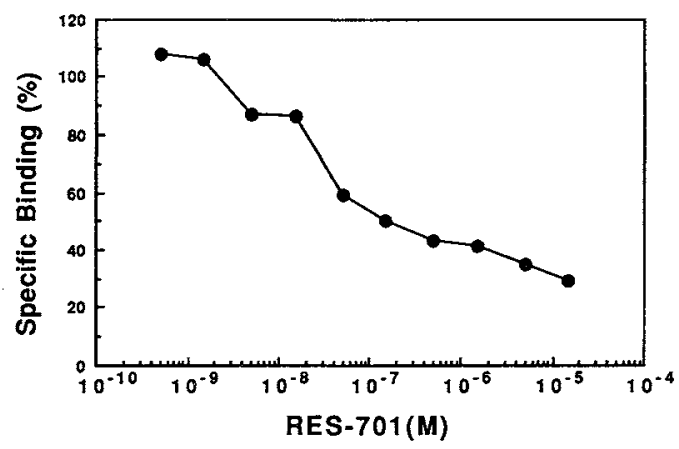

Fig. 3 shows an inhibitory effect of RES-701-1 on $\left[{ }^{125} \mathrm{I}\right] \mathrm{ET}-1$ binding to bovine lung membranes. RES-701-1 inhibited $\left[{ }^{125} \mathrm{I}\right] \mathrm{ET}-1$ binding in a dose-dependent manner with and $\mathrm{IC}_{50}$ of $0.15 \mu \mathrm{M}$. However, even at $15 \mu \mathrm{M}, 100$ times higher concentra-

Fig. 2. The structure of RES-701-1.

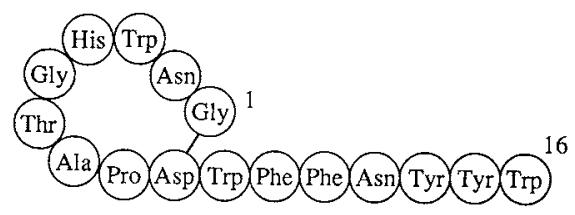

Table 4. Effect of RES-701-1 on $\left[{ }^{125} \mathrm{I}\right] \mathrm{ET}-1$ binding to two distinct subtypes of endothelin receptor stably expressed in CHO cells.

\begin{tabular}{cc}
\hline Endothelin receptor subtype & $\mathrm{IC}_{50}(\mathrm{nM})$ \\
\hline Human $\mathrm{ET}_{\mathbf{A}}$ & $>5,000$ \\
Human $\mathrm{ET}_{\mathbf{B}}$ & 10 \\
\hline
\end{tabular}

Table 5. Effects of RES-701-1 on intracellular $\mathrm{Ca}^{2+}$ concentration $\left(\left[\mathrm{Ca}^{2+}\right]^{\mathrm{i}}\right)$ induced by $\mathrm{ET}-1$ in $\mathrm{ET}_{\mathrm{B}}$ receptor expressing COS-7 cells.

\begin{tabular}{cc}
\hline RES-701-1 $(\mu \mathrm{M})$ & {$\left[\mathrm{Ca}^{2+}\right]^{\mathrm{i}}(\mathrm{nM})$} \\
\hline 0 & $61.7 \pm 5.58$ \\
0.49 & $24.8 \pm 3.64$ \\
4.9 & $3.67 \pm 1.08$ \\
\hline
\end{tabular}


tion than the $\mathrm{IC}_{50}$ value, RES-701-1 could not displace completely the specific binding of $\left[{ }^{125} \mathrm{I}\right] \mathrm{ET}-1$, suggesting that RES-701-1 selectively recognized type A or type Bendothelin receptor in bovine lung membranes. Table 4 shows an inhibition of $\left[{ }^{125}\right.$ I]ET-1 binding to cloned human type $A$ and type $B$ endothelin receptors expressed in CHO cells. RES-701-1 inhibited [ $\left.{ }^{125} \mathrm{I}\right] \mathrm{ET}-1$ binding to type $\mathrm{B}$ receptor $\left(\mathrm{ET}_{\mathrm{B}}\right)$ with an $\mathrm{IC}_{50}$ of $10 \mathrm{nM}$, but had no effect on $\left[{ }^{125} \mathrm{I}\right] \mathrm{ET}$-1 binding to type $\mathrm{A}$ receptor $\left(\mathrm{ET}_{\mathrm{A}}\right)$ even at $5 \mu \mathrm{M}$. Table 5 summarizes the effects of RES-701-1 on ET-1-induced increase in intracellular $\mathrm{Ca}^{2+}$ concentration $\left(\left[\mathrm{Ca}^{2+}\right]^{\mathrm{i}}\right)$ in $\mathrm{ET}_{\mathrm{B}}$ expressing COS-7 cells. At $4.9 \mu \mathrm{M}$, RES-701-1 completely abolished the elevation of $\left[\mathrm{Ca}^{2+}\right]^{\mathrm{i}}$ caused by $1 \mathrm{nM}$ of ET-1. Taken together, these results indicate that RES-701-1, a novel cyclic peptide of microbial origin, is a selective antagonist for type B endothelin receptor.

\section{Discussion}

The recognition of the potential therapeutic benefit of controlling endogeneous endothelin activity has led to a search for endothelin antagonists by a random screening approach. Recently, several endothelin receptor antagonists have been found in microbial metabolites or plant extracts, namely, type A selective antagonist BE- $18257 \mathrm{~B}^{8)}, 50-235^{9)}$, WS- $7338^{10)}$ and nonselective antagonist cochinmicins ${ }^{11}$. Among these antagonists obtained from natural products, RES-701-1 is the first compound that selectively recognizes type B endothelin receptor.

Although two human subtypes of endothelin receptor have been cloned ${ }^{7,12)}$ and their differential mRNA distribution have been studied ${ }^{13)}$, there remains to be elucidated as to which subtype is responsible for the effects of endothelin in a given condition. RES-701-1, type B selective endothelin receptor antagonist, will be important tool for elucidating the relative contribution of two distinct subtypes of endothelin receptor in various physiological or pathophysiological conditions.

\section{Acknowledgment}

We would like to thank Mrs. CHIEKo IWAHASH for fermentations and binding assays, and Dr. SHIGEHISA HiRose for the generous gift of cDNA encoding human $\mathrm{ET}_{\mathrm{B}}$ receptor.

\section{References}

1) Miller, R. C.; J. T. Pelton \& J. P. Huggins: Endothelins-from receptors to medicine. Trends. Pharmacol. Sci. 14: $54 \sim 60,1993$

2) Haynes, W. G.; A. P. DavenPort \& D. J. Webi: Endothelin: progress in pharmacology and physiology. Trends. Pharmacol. Sci. 14: 225 228, 1993

3) YamaSaki, M.; K. Yano, M. Yoshida, Y. Matsuda \& K. Yamaguchi: RES-701-1, a novel and selective endothelin type B receptor antagonist produced by Streptomyces sp. RE-701. II. Determination of the primary sequence. J. Antibiotics 47: 276 280, 1994

4) Shirling, E. B. \& D. Gottlieb: Methods for characterization of Streptomyces species. Int. J. Syst. Bacteriol. 16: $313 \sim 340,1966$

5) Hasegawa, T.; M. Takizawa \& S. Tanida: A rapid analysis for chemical grouping of aerobic actinomycetes. J. Gen. Appl. Microbiol. 29: 319 322, 1983

6) Mivait, H.; H. Harada, T. Mizukami, S. Sato, N. Fujiyoshi \& S. Iroh: Efficient expression of human betainterferon in Namalwa KJM-1 cells adapted to serum-free medium by a dhfr gene coamplification method. Cytotechnology 4: 173 180, 1990

7) Sakurai, T.; M. Yanagisawa, Y. Takuwa, H. Miyazaki, S. Kimura, K. Goto \& T. Masaki: Cloning of a cDNA encoding a non-isopeptide-selective subtype of the endothelin receptor. Nature 348: 732 735, 1990

8) Ihara, M.; T. Fukuroda, T. Saeki, M. Nishikibe, K. Kojiri, H. Suda \& M. Yano: An endothelin receptor (ET A $_{\text {) }}$ antagonist isolated from Streptomyces misakiensis. Biochem. Biophys. Res. Commun. 178: 132 137, 1991

9) Fummoto, M.; S. Mihara, S. Nakajima, M. Ueda, M. Nakamura \& K. Sakurai: A novel non-peptide antagonist isolated from bayberry, Myrica cerifica. FEBS lett. 305: 41 44, 1992

10) Miyata, S.; M. Hashimoto, Y. Masui, M. Ezaki, S. Takase, M. Nishikawa, S. Kiyoto, M. Okuhara \& M. KoHSAKA: WS-7338, new endothelin receptor antagonists isolated from Streptomyces sp. No. 7338. I. Taxonomy, 
fermentation, isolation, physico-chemical properties and biological activities. J. Antibiotics 45: 74 82, 1992

11) Lam, Y. K. T.; D. L. Williams, Jr., J. M. Sigmund, M. Sanchez, O. Genilloud, Y. L. Kong, S. Stevens-Miles, L. Huang \& G. M. Garrity: Cochinmicins, novel and potent cyclodepsipeptide endothelin antagonists from a Microbispora sp. I. Production, isolation, and characterization. J. Antibiotics 45: 1709 1716, 1992

12) Arai, H.; S. Hori, I. Aramori, H. Ohkubo \& S. Nakanishi: Cloning and expression of a cDNA encoding an endothelin receptor. Nature 348: 730 732, 1990

13) Hori, S.; Y. Komatsu, R. Shigemoto, N. Mizuno \& S. Nakanishi: Distinct tissue distribution and celular localization of two messenger ribonucleic acids encoding different subtypes of rat endothelin receptors. Endocrinology 130: 1885 1895, 1992 